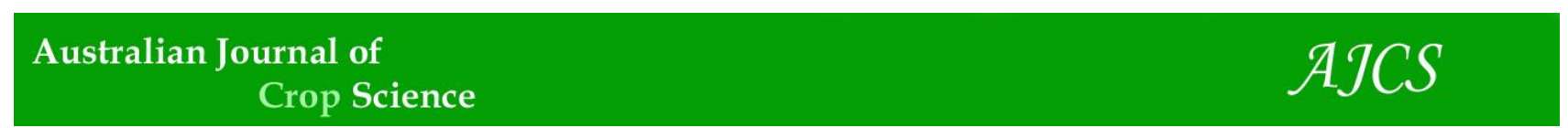

AJCS 12(06):954-960 (2018)

ISSN:1835-2707

doi: 10.21475/ajcs.18.12.06.PNE1049

\title{
Germination of guar (Cyamopsis tetragonoloba (L.) Taub.) genotypes with reduced temperature requirements
}

\author{
Fabio Gresta ${ }^{1 *}$, Antonia Cristaudo ${ }^{2}$, Calvin Trostle ${ }^{3}$, Umberto Anastasi ${ }^{4}$, Paolo Guarnaccia ${ }^{4}$, Stefania \\ Catara $^{2}$, Andrea Onofri ${ }^{5}$
}

${ }^{1}$ Dipartimento di Agraria, University of Reggio Calabria, Loc. Feo di Vito, 89122, Reggio Calabria, Italy

${ }^{2}$ Dipartimento di Scienze Biologiche, Geologiche e Ambientali, University of Catania, Via Empedocle, 58, 95128

Catania, Italy

${ }^{3}$ Texas A\&M AgriLife Extension, Lubbock, Texas USA

${ }^{4}$ Dipartimento Agricoltura, Alimentazione e Ambiente, University of Catania, Via Valdisavoia, 595123 Catania, Italy

${ }^{5}$ Dipartimento di Scienze Agrarie, Alimentari ed Ambientali, University of Perugia, Borgo XX Giugno 74, 06121,

Perugia, Italy

*Corresponding author: fgresta@unirc.it

Abstract

Guar (Cyamopsis tetragonoloba (L.) Taub.) is an annual legume with a long crop cycle and high temperature threshold for seed germination $\left(20-21^{\circ} \mathrm{C}\right)$. In semi-arid Mediterranean areas, inadequate soil warmth delays guar planting to May/early June and harvest to October-November, when high rainfall hinders seed maturation and lowers gum quality. Nine world guar genotypes (from India, Pakistan, USA, South Africa) were tested for germination capability and speed in response to temperature. All source seeds were field grown in Sicily for use in germination assays. The following temperature regimes were imposed adopting a completely randomized design: A) seven constant temperatures from $5^{\circ} \mathrm{C}$ to $35^{\circ} \mathrm{C}\left(5^{\circ} \mathrm{C}\right.$ increments), and $\left.\mathrm{B}\right)$ two alternating temperatures of $15 / 10^{\circ} \mathrm{C}$ and $20 / 15^{\circ} \mathrm{C}(6 \mathrm{~h} / 18 \mathrm{~h}$ thermoperiod), each consisting of four replicates of 25 seeds. Optimal germination temperatures were always 30 and $35^{\circ} \mathrm{C}$, but Indian genotypes also demonstrated substantial germination percentages (33-43\%) at constant temperatures as low as $15^{\circ} \mathrm{C}$. Mean germination time (MGT) of genotypes India2, Kinman, Lewis, and Monument were 1.1 to 1.7 days at 30 and $35^{\circ} \mathrm{C}$. At lower temperatures $\left(15^{\circ} \mathrm{C}\right)$, the germination percentage and MGT improved significantly when the seeds were exposed at $20^{\circ} \mathrm{C}$ for 6 hours a day. In particular, Kinman, India2 and Monument gave good results, achieving $80 \%, 76 \%$ and $66 \%$ germination, respectively, with MGTs of 5 days. This alternating temperature regime is typical in soil during the Mediterranean spring. Results may be useful both for farmers to identify optimum timing for guar sowing, and for breeders to cross genotypes that tolerate low germination temperatures with high yielding genotypes.

Keywords: Guar, seed germination, mean germination time, genotypes, constant temperature, alternating temperature.

Introduction

Guar (Cyamopsis tetragonoloba (L.) Taub.) is a low-input annual legume species (Gresta et al., 2014), with a springsummer cycle, mainly grown in India $(80 \%$ of the world's production), Pakistan (15\%), Sudan and the United States (Sharma, 2010). It is a self-pollinated crop, extremely drought-tolerant, with good adaptability to a wide range of soil conditions, even though it performs best in sandy soils. It tolerates salinity and low fertility soils (Ashraf et al., 2002; Ashraf et al., 2005) and is an excellent soil-building crop due to potential Bradyrhizobium nodulation or other crop rotation benefits (Elsheikh and Ibrahim, 1999; Tripp et al., 1977).

Guar has long been cultivated as a vegetable, green manure and forage crop mainly in South Asia. From the 1950's it has assumed an important role among industrial crops since it has been adopted as the substitute for carob in the paper industry (Abidi et al., 2015). In fact, the galactomannans extracted from the endosperm show thickening, stabilizing, sizing and strengthening properties and they improve handling, viscosity and shelf life of numerous materials including industrial products and foods, even at low concentrations and low temperatures (Mathur 2012). Currently, guar galactomannans are used in many industrial activities, such as food, paper, explosives, textiles, oil well drilling and fracking, cosmetics and pharmaceutical industries (Abidi et al., 2015; Mudgil et al., 2014; Vaughn et al., 2011; Lubbe and Verpoorte, 2011). Moreover, after the extraction of the endosperm, the by-product is considered a valuable feed supplement for animals due to its high protein content (Chiofalo et al., 2018; Gresta et al., 2017).

Previous research demonstrates the adaptability of guar to irrigated Mediterranean environments (Sortino and Gresta, 2007; Gresta et al., 2014; Gresta et al., 2016a), although some obstacles remain for widespread cultivation on a field scale. One of the main problems in these environments is 
the excessive length of the crop cycle, which may take more than 160 days, in the case of late genotypes.

Moreover, guar needs high soil temperatures of at least $20-21^{\circ} \mathrm{C}$ for adequate seed germination, while the optimal temperature is considered $30^{\circ} \mathrm{C}$ (Undersander et al., 1991). In Mediterranean areas, such temperatures impose a sowing time no earlier than May-early June (Gresta et al., 2013), thus harvest is delayed until November, after a rainy period in late summer/early autumn. Consequently, late autumn rain may cause increased blackening of seeds, which results in a potentially significant decrease in yield, seed gum quality and commercial value (Liu et al., 2007). Moreover, such a late harvest does not fit well with the typical Mediterranean crop rotation systems, which are frequently based on autumn sown wheat and other cereals.

A possible way to overcome the above-mentioned problems could be selection of genotypes with lower temperature requirements for germination. In fact, genotypes with good germination ability at $15^{\circ} \mathrm{C}$ would permit sowing at the beginning of April and, consequently, anticipate harvest at least 30 days sooner, in a more favorable time of the year.

Temperature is one of the main environmental factors affecting seed germination. Previous studies have shown wide inter-specific and intra-specific variability in terms of base temperature and optimal temperature levels. Furthermore, threshold temperatures may also change in response to temperature regimes, depending on the existence and amplitude of daily fluctuations (Probert, 1992; Kigel, 1995).

Despite its widespread importance as an industrial crop, guar has received little attention from the research community, including aspects related to seed germination. Image analysis has been conducted on guar seed (Gresta et al., 2016b), but without giving any information on how imaging results might describe germination ability. A few guar germination trials have been conducted for the assessment of seed germination capability (Iqbal, 2015; Teolis et al., 2009; Ramarajan et al., 2013). Therefore, the objective of the present research was to test nine different world guar genotypes with respect to their germination behavior at seven constant temperatures plus two alternating temperature cycles, focusing on the key temperatures that could allow earlier sowing in semi-arid Mediterranean-type environments.

\section{Results and Discussion}

Germination at constant temperature from $5^{\circ} \mathrm{C}$ to $35^{\circ} \mathrm{C}$ Germination was significantly affected by genotype, temperature and their interaction (Figure 1). No germination was observed at 5 and $10^{\circ} \mathrm{C}$ for all genotypes. For Kinman, Lewis and South Africa, negligible or no germination was observed at $15^{\circ} \mathrm{C}$. Germination increased sharply in Kinman and Lewis, from less than $5 \%$ at $15^{\circ} \mathrm{C}$ to $98 \%$ and $68 \%$, respectively, at $20^{\circ} \mathrm{C}$. For the other genotypes, the temperature-dependent increase in germination percentage was more gradual: germination in Indian genotypes, Monument and Pakistan showed moderate germination (from 25 to $50 \%$ ) at $15^{\circ} \mathrm{C}$, and further increase in germination at higher temperature, reaching over $75 \%$ germination. Matador and South Africa showed a contrasting pattern with a low increase at $15^{\circ} \mathrm{C}$, reaching the maximum percentage of germination at $30^{\circ} \mathrm{C}$, with values no higher than $80 \%$ (Fig. 1).

For all genotypes, maximum germinated percentages were obtained at $25^{\circ} \mathrm{C}$ or $30^{\circ} \mathrm{C}$, reaching values up to $100 \%$. Pakistan and Matador showed a strong decrease in germination at $35^{\circ} \mathrm{C}$, while all other guar genotypes were less hindered by the highest temperature.

It is widely known that temperature has a strong effect not only on germination capability, but also on germination speed, which is an important parameter for field sowing. Mean Germination Time (MGT) decreased as temperature increased from $15^{\circ} \mathrm{C}$ to $30^{\circ} \mathrm{C}$ and, for some genotypes, to $35^{\circ} \mathrm{C}$ (Figure 2). High MGTs (over $20 \mathrm{~d}$ ), which indicate slow germination, were observed in South Africa (23.2 d \pm 1.8 ), Monument $(21.2 \mathrm{~d} \pm 1.6)$ and Kinman $(20.5 \mathrm{~d} \pm 2.2)$ at $15^{\circ} \mathrm{C}$.

Also at $15^{\circ} \mathrm{C}$, intermediate MGTs were observed in Indian genotypes (17.2 d, on average), while the shortest MGT, which corresponds to fast germination, was observed in Matador (12.1 $d \pm 0.9$ ), which showed also the shortest MGT at higher temperatures, with values of $1.2 \mathrm{~d} \pm 0.1$ and $0.6 \mathrm{~d}$ \pm 0.04 at 25 and $35^{\circ} \mathrm{C}$, respectively.

Favorable MGTs at 30 and $35^{\circ} \mathrm{C}$ ranged from 1.0 to $2.3 \mathrm{~d}$ in Kinman, Monument, India2, Lewis, Pakistan, India1 and India3. Contrarily, at $30^{\circ} \mathrm{C}$ and $35^{\circ} \mathrm{C}$, South Africa showed higher MGTs (6.5 d \pm 0.5 and $5.0 d \pm 0.4$ ). Our data are in partial agreement with those of Undersander et al. (1991) who reported a threshold soil temperature for seed germination equal to $21^{\circ} \mathrm{C}$ and an optimal temperature equal to $30^{\circ} \mathrm{C}$. The same information is reported by FaridahHanum and van der Maesen (1997) and Hymowitz and Matlock (1964). In our trial, some genotypes were also able to germinate at less than $20^{\circ} \mathrm{C}$, though with low germination capability and speed. In fact, all three Indian genotypes, and to a lesser extent, Monument, Pakistan and Matador germinated at $15^{\circ} \mathrm{C}$, with germination percentages ranging from $20 \%$ to $43 \%$.

Relating to optimum germination temperature, $\mathrm{Hu}$ et al. (2002) suggested that the temperature at which guar seed germinates most quickly is $27^{\circ} \mathrm{C}$. Vinisky and Ray (1985) found no differences in guar germination responses at four temperatures between $25^{\circ} \mathrm{C}$ and $37^{\circ} \mathrm{C}$, but they found a significant temperature-salinity interaction, reporting a severe decrease in germination with the combination of high temperatures $\left(34^{\circ} \mathrm{C}\right.$ and $\left.37^{\circ} \mathrm{C}\right)$ and high salt concentrations (-1.1 and $-1.5 \mathrm{MPa})$. Our data are also in agreement with Liu et al. (2007) who tested three guar genotypes (including Lewis) at $22{ }^{\circ} \mathrm{C}$ under dark conditions where they obtained germination between 85 and 95\%. Working with 41 accessions (including Kinman and Lewis) in a germination trial in the dark at $20 / 21^{\circ} \mathrm{C}$, Teolis et al. (2009) obtained germination percentages always over $90 \%$, except for one of the two Lewis accessions (85\%).

\section{Germination at two alternating temperature regimes $\left(15 / 10\right.$ and $\left.20 / 15^{\circ} \mathrm{C}\right)$}

In contrast to constant temperatures, guar genotypes showed a completely different behavior at alternating temperatures. At $15 / 10^{\circ} \mathrm{C}$, negligible germinations were observed: $4 \%$ in India2 and $2 \%$ in Matador (data not shown). On the other hand, at $20 / 15^{\circ} \mathrm{C}$, Kinman, India2, and Monument showed germination percentages over $60 \%$ (Fig 3). The capability of germination for these three genotypes 
Table 1. Origin of the nine guar genotypes planted in Plain of Gela, Sicily, 2012.

\begin{tabular}{lcc}
\hline Genotypes & Origin & Growth Habit \\
\hline India 1 & India & Single stem \\
India 2 & India & Single stem \\
India 3 & India & Single stem \\
Kinman & Texas (USA) & Branching \\
Lewis & Texas (USA) & Fine branching \\
Matador & Texas (USA) & Branching \\
Monument & Texas (USA) & Single stem \\
Pakistan & Pakistan & Branching \\
South Africa & Pakistan & Wide branching \\
\hline
\end{tabular}

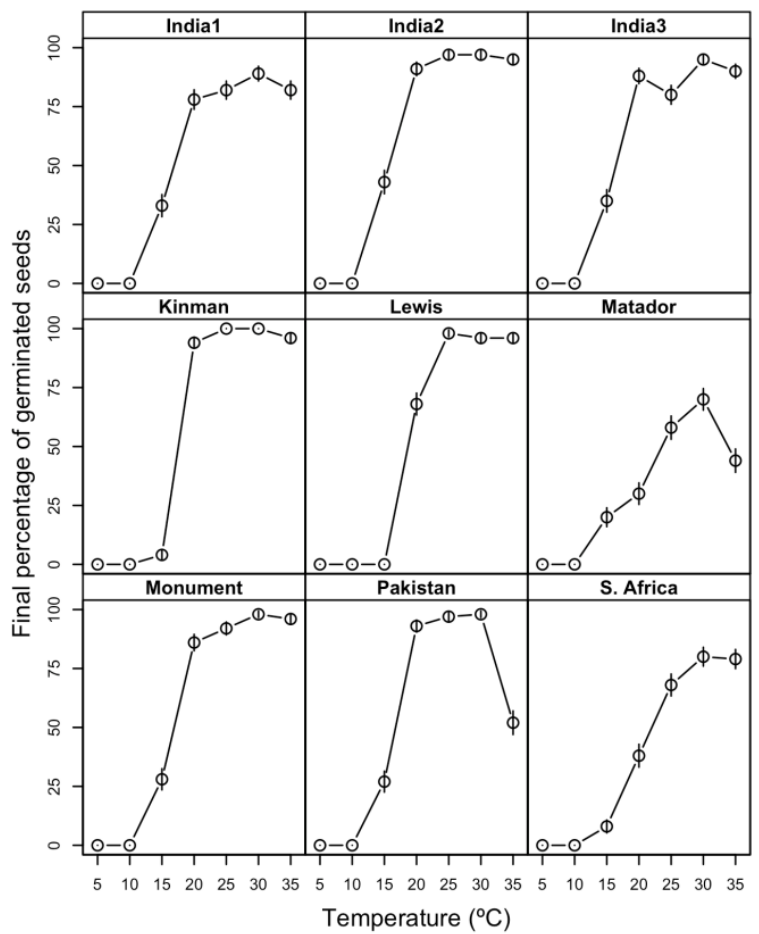

Fig 1. Percentage of germinated seeds for nine world guar genotypes, after 25 days in a darkened growth chamber at fixed temperatures ranging from $5^{\circ} \mathrm{C}$ to $35^{\circ} \mathrm{C}$. Source seed was grown in the Plain of Gela, Sicily, 2012. Vertical bars represent SEs.

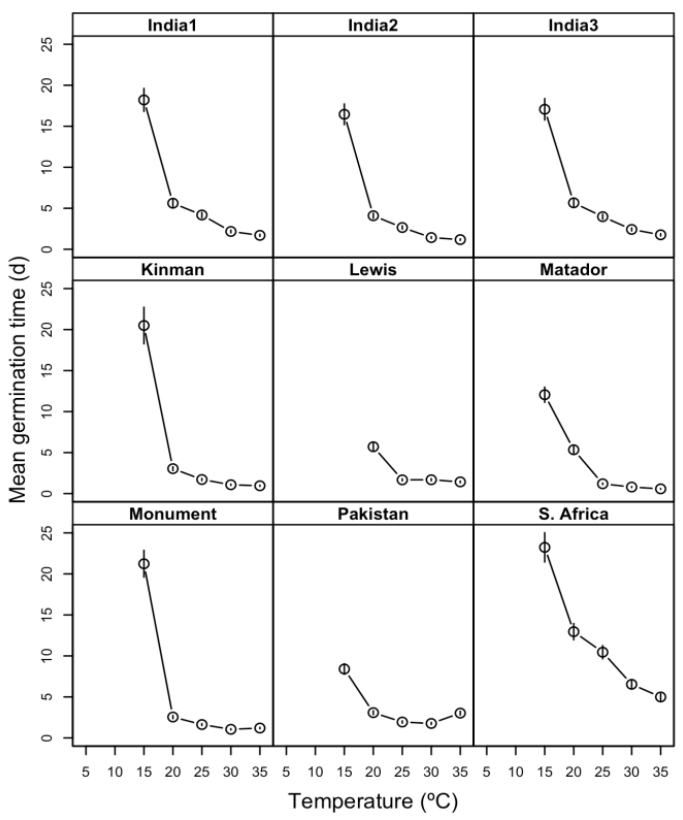

Fig 2. Mean germination time (MGT) of nine world guar genotypes assessed for 25 days at constant temperatures ranging from $5^{\circ} \mathrm{C}$ to $35^{\circ} \mathrm{C}$. Vertical bars represent SEs. No MGT was calculated for any Petri dish with less than $10 \%$ of final percentage of germinated seeds. 


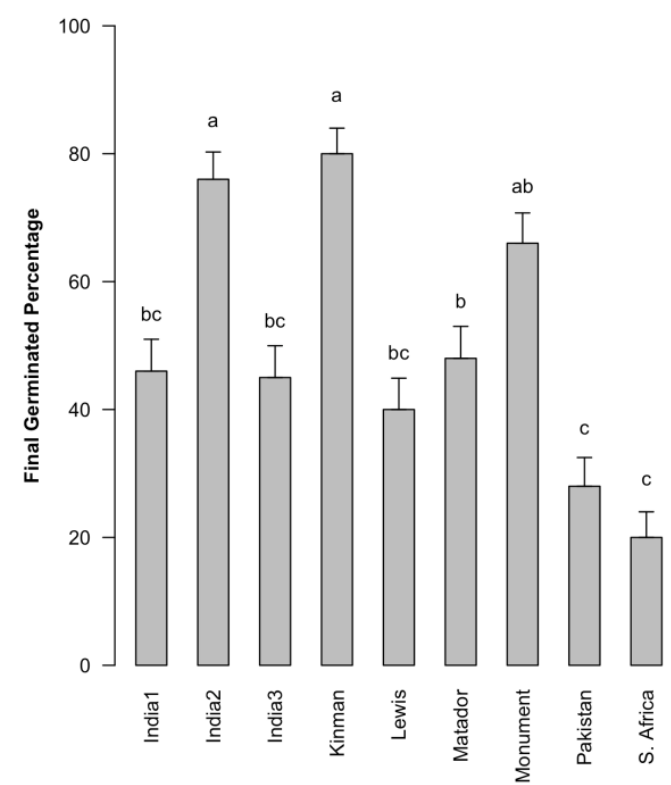

Fig 3. Percentage of germinated seeds for nine world guar genotypes, after 25 days in a darkened growth chamber at alternating $20^{\circ} \mathrm{C} / 15^{\circ} \mathrm{C}(6 / 18 \mathrm{~h})$. Vertical bars represent SEs. Bars with different letters are significantly different $(\mathrm{P}<0.05)$.

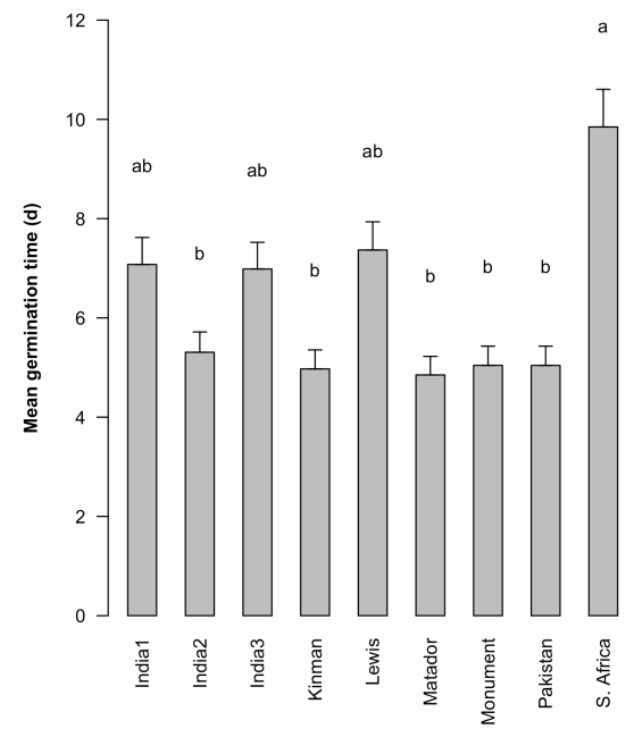

Fig 4. Mean germination time (MGT) of nine world guar genotypes assessed at alternating temperatures $20^{\circ} \mathrm{C} / 15^{\circ} \mathrm{C}(6 / 18 \mathrm{~h})$ for possible earlier spring planting under cooler soil conditions. Vertical bars represent SEs. Bars with different letters are significantly different $(P<0.05)$.

was not as high as at constant $20^{\circ} \mathrm{C}$, but germination was much higher than at constant $15^{\circ} \mathrm{C}$. Apart from the above mentioned three varieties, germination above $40 \%$ was observed also in India1, India3, Lewis and Matador, while in Pakistan and South Africa a lower germination (28 and 20\%, respectively) was recorded. As expected, MGTs at $20 / 15^{\circ} \mathrm{C}$ were high, but suitable for an earlier spring field sowing (Fig 4). The lowest MGT values were observed in Matador, Kinman, Monument, Pakistan and India2 (5.0 d \pm 0.4 , on average). A greater MGT was measured in India1 and India3 (7.0 $d \pm 0.5$, on average), Lewis (7.4 $d \pm 0.6$ ) and South Africa $(9.8 d \pm 0.8)$. Considering the thermal period adopted for this experiment, results suggest that it is possible to obtain adequate germination and crop establishment by sowing early in spring, if $20^{\circ} \mathrm{C}$ is reached for 6 hours a day. In this respect, matching high germination values with low mean germination times, we suggest that Kinman and India 2 might be the best options, having reached $80 \%$ and $76 \%$ of germination in 5 days. With these varieties, although at the cost of using higher seeding rates, the sowing date may be anticipated, by exploiting the time-window when daily soil temperature highs are between $15^{\circ} \mathrm{C}$ and $20^{\circ} \mathrm{C}$. This information could be useful for those farmers who want to explore the possibility of an early guar sowing, to better fit in with their cropping systems. 
No germination trials at alternating temperatures have been reported for guar. Compared to cool-season legumes, such as Scorpiurus spp. (Gresta et al., 2007a), annual medics (Gresta et al., 2007b) and Lotus spp. (Gresta et al., 2011), guar showed a much lower degree of hard seed, but a clearly higher threshold temperature for seed germination. Furthermore, compared to soybean and other warm-season legumes, guar exhibited a higher germination temperature; indeed, with respect to guar, some varieties of soybean were able to germinate at lower temperatures $\left(10^{\circ} \mathrm{C}\right.$ and $15^{\circ} \mathrm{C}$ ), reaching up $54-62 \%$ germination at $10^{\circ} \mathrm{C}$ (Brar et al., 1991; Butler et al., 2014). On seven annual warm-season and eleven annual cool-season legumes, Butler et al. (2014) found that germination of warm-season legumes tended to be maximized at $25^{\circ} \mathrm{C}$, while the germination of cool-season legume was greatest from 10 to $25^{\circ} \mathrm{C}$. The optimal temperature for both germination and seedling growth are adaptive traits to the environment of origin of the species (Motsa et al., 2015). For this reason, guar shows best germination at high day-time temperatures, which are characteristic of tropical and subtropical regions.

\section{Materials and methods}

\section{Plant materials}

The trial was conducted in 2013 on nine guar genotypes originating from different world sources (Table 1).

Genotypes were chosen following those tested in the Mediterranean environment by Gresta et al. (2016a). The American varieties (Kinman, Lewis, Matador and Monument) were supplied by the Texas A\&M AgriLife Extension Service. India1, India2 and India3 are Indian genotypes and were purchased from an international seller, who was unable to provide any detail about their characteristics or genetic background. However, these genotypes are marketed for planting seed in Rajasthan, India. A Pakistan genotype was also obtained and included in the experiment. Finally, a well-adapted genotype grown in South Africa was included, though it originated in Pakistan.

To avoid any possible effect deriving from stress experienced by the seeds during maturation on the mother plant in the environment of origin, the nine genotypes were sown in the beginning of May 2012 in the Plain of Gela $(60 \mathrm{~m}$ a.s.l., $\left.37^{\circ} 03^{\prime} 01^{\prime \prime} \mathrm{N}, 14^{\circ} 20^{\prime} 25^{\prime \prime} \mathrm{E}\right)$, Sicily, Southern Italy. The Plain of Gela is a suitable Mediterranean environment for guar cultivation since it is characterized by hot summers and moderate water availability. In 2012, air temperature ranged from $11.5^{\circ} \mathrm{C}$ in February to $29.2^{\circ} \mathrm{C}$ in August; total rainfall was $532 \mathrm{~mm}, 95 \%$ of which concentrated in January-April and September-December. Weeds were controlled with pendimethalin and imazamox as recommended for grain legumes (Avola et al., 2008). The plots were fully irrigated, with approximately $2,500 \mathrm{~m}^{3} \mathrm{ha}^{-1}$, to avoid any problems due to water stress. They were hand harvested in October, when the seeds were fully mature. Immediately after harvest, intact seeds were selected, packed and stored in a refrigerator at $4^{\circ} \mathrm{C}$ for three months.

\section{Experimental design and germination tests}

Nine treatments (seven at constant and two at alternating temperatures) consisting of 4 replicates of 25 seeds each, were arranged in a completely randomized design. Seeds were placed on Whatman No. 3 filter paper in $9 \mathrm{~cm}$ Petri dishes. The Petri dishes were incubated in thermostatically controlled germination chambers (Sanyo - model MLR-35H, Tokyo, Japan). The paper sheet was soaked with $5 \mathrm{ml}$ of distilled water at the beginning of the test, and replenished as needed in the following days. To explore the effect of temperature on seed germination, seven treatments of different constant temperatures were initiated from $5^{\circ} \mathrm{C}$ to $35^{\circ} \mathrm{C} \pm 1^{\circ} \mathrm{C}$ in increments of $5^{\circ} \mathrm{C}$ in continuous darkness to simulate soil conditions at sowing. In order to simulate the daily trend of soil temperatures during the guar sowing time in Mediterranean regions, two additional treatments with alternating temperatures $\left(15 / 10^{\circ} \mathrm{C}\right.$ and $20 / 15^{\circ} \mathrm{C}$ for $6 / 18$ hours thermal period) under dark were imposed. The dark treatment was imposed by wrapping Petri dishes with a double layer of aluminum foil.

In order to ascertain seed viability for germination testing, the seed coat of an extra seed-lot for each variety was scarified by abrasion with sand paper and tested in preliminary germination assays at $30^{\circ} \mathrm{C}$ (optimal temperature, Undersander et al., 1991). The presence of abrasion was confirmed with a microscope, and all scarified seeds germinated.

Germination dishes were monitored daily for 25 days, and seeds with visible radicle protrusion (exceeding $2 \mathrm{~mm}$ ) were counted and removed from the Petri dishes. The seeds under dark conditions were monitored with a green safety light to eliminate red-far red light effects on seed germination.

Non-viable seeds were identified based on their softness and brownish color and were not considered in data analyses. Seeds infected by fungi were considered as not germinated. No fungicide treatment was used to avoid possible interference of the active ingredient on germination of seeds.

\section{Data collection and statistical analyses}

At the end of the trial, the Final Germinated Percentage (FGP) for each Petri dish was calculated from the total number of seeds germinated divided by the total number of viable seeds tested and multiplied by 100 .

Speed of germination was also determined by considering the mean germination times (MGTs), i.e. the average value of the time to germination for all germinated seeds in each Petri dish. MGTs were derived from Kaplan-Meyer estimators of germination curves with mid-point imputation (Law and Brookmeyer, 1992). These estimators are similar to traditional MGT estimators (Ranal and Santana, 2006), although they are preferable as they can more reliably account for all types of uncertainty in measuring germination times for each seed in the lot (Onofri et al., 2010). No MGT was calculated for any Petri dishes with less than $10 \%$ of FGP.

For FGPs, the corresponding proportion was analyzed using a Generalized Linear Model with binomial error and logit link. The significance of genotype and temperature effects, as well as their interaction was tested by using Wald-tests. Back-transformed percentages were derived together with delta standard errors and they were reported in graphs (Faraway, 2006).

For MGTs, data were log-transformed and submitted to ANOVA, to test the significance of the above-mentioned effects. Back-transformed means together with delta 
standard errors are reported in the figures. Differences between back-transformed means were tested by using the general procedure suggested in Hothorn et al. (2008), together with a single-step multiplicity adjustment.

\section{Conclusion}

In conclusion, this research suggests that, even though minimal threshold germination temperature for guar is considered $20^{\circ} \mathrm{C}$, some genotypes such as Indian (33-43\%) and, to a lesser extent, Pakistan and Monument (27-28\%) showed limited germination even at constant temperature of $15^{\circ} \mathrm{C}$. Optimal temperatures range from 25 to $35^{\circ} \mathrm{C}$. Furthermore, alternating temperatures $\left(20 / 15^{\circ} \mathrm{C}, 6 / 18 \mathrm{~h}\right)$ as commonly found in soil in the Mediterranean environment at the beginning of April strongly enhance germination compared to a constant temperature of $15^{\circ} \mathrm{C}$ : in this case, it was possible to reach high germination percentages in Kinman (80\%), India2 (76\%) and Monument (66\%). The results of this trial could be helpful for researchers and farmers to better understand opportunities for early spring sowing in relation to temperature and could be exploited also for breeding purposes, crossing genotypes that tolerate low germination temperatures with high yielding genotypes.

\section{References}

Abidi N, Liyanage S, Auld D, Imel RK, Norman L, Grover K, Sangu A, Singla S, Trostle C (2015) Challenges and opportunities for increasing guar production in the United States to support unconventional oil and gas production. In: Uddameri V. et al. (eds) Hydraulic fracturing impacts and technologies. CRC Press, Taylor \& Francis Group, Boca Raton.

Ashraf MY, Akhtar K, Sarwar G, Ashraf M (2002) Evaluation of arid and semiarid ecotypes of guar (Cyamopsis tetragonoloba L.) for salinity ( $\mathrm{NaCl})$ tolerance. J Arid Environ. 52: 473-482.

Ashraf MY, Akhtar K, Sarwar G, Ashraf M (2005) Role of the rooting system in salt tolerance potential of different guar accessions. Agron Sustain Dev. 25: 243-249.

Avola G, Tuttobene RM, Gresta F, Abbate V (2008) Weed control strategies for grain legumes. Agron Sustain Dev. 28: 389-396.

Brar GS, Gomez JF, McMichael BL, Matches AG, Taylor HM (1991) Germination of twenty forage legumes as influenced by temperature. Agron J. 83: 173-175.

Butler TJ, Celen AE, Webb SL, Krstic D, Interrante SM (2014) Temperature affects the germination of forage legume seeds. Crop Sci. 54: 2846-2853.

Chiofalo B, Lo Presti V, D'Agata A, Raso R, Ceravolo G, Gresta $F(2018)$ Qualitative profile of degummed guar (Cyamopsis tetragonoloba L.) seeds grown in a Mediterranean area as alternative protein source for animal feed. J Anim Physiol Anim Nutr. https://doi.org/10.1111/jpn.12687.

Elsheikh EAE, Ibrahim KA (1999) The effect of Bradyrhizobium inoculation on yield and seed quality of guar (Cyamopsis tetragonoloba L.). Food Chem. 65: 183187.

Faraway JJ (2006) Extending the linear model with R. Generalized linear, mixed effects and nonparametric regression models. Texts in statistical sciences. Chapman \& Hall Books, Boca Raton.
Faridah-Hanum I, van der Maesen LJG (1997) Plant resources of South-East Asia. Auxiliary plants. Prosea Foundation, Bogor.

Gresta F, Avola G, Abbate V (2007a) Germination ecology of Scorpiurus subvillosus L. seeds: the role of temperature and storage time. Plant Ecol. 190: 123-130.

Gresta F, Avola G, Anastasi U, Miano V (2007b) Effect of maturation stage, storage time and temperature on seed germination of Medicago species. Seed Sci Technol. 35: 698-708.

Gresta F, Avola G, Onofri A, Anastasi U, Cristaudo A (2011) When does hard coat impose dormancy in legume seeds? Lotus and Scorpiurus case-study. Crop Sci. 51: 1739-1747.

Gresta F, Ceravolo G, Lo Presti V, D'Agata A, Rao R, Chiofalo B (2017) Seed yield, galactomannan content and quality traits of different guar (Cyamopsis tetragonoloba L.) genotypes. Ind Crops Prod. 107: 122-129.

Gresta F, De Luca Al, Strano A, Falcone G, Santonoceto C, Anastasi U, Gulisano G (2014) Economic and environmental sustainability analysis of guar (Cyamopsis tetragonoloba L.) farming process in a Mediterranean area: two case studies. Ital J Agron. 9: 20-24.

Gresta F, Mercati F, Santonoceto C, Abenavoli MR, Ceravolo G, Araniti F, Anastasi U, Sunseri F (2016a) Morphoagronomic and AFLP characterization to explore guar (Cyamopsis tetragonoloba L.) genotypes for the Mediterranean environment. Ind Crops Prod. 86: 23-30.

Gresta F, Santonoceto C, Ceravolo G, Formantici C, Grillo O, Ravalli C, Venora G (2016b) Productive, qualitative and seed image analysis traits of guar (Cyamopsis tetragonoloba (L.) Taub). Austral J Crop Sci. 10: 1052-1060.

Gresta F, Sortino O, Santonoceto C, Issi L, Formantici C, Galante YM (2013) Effects of sowing times on seed yield, protein and galactomannans content of four varieties of guar (Cyamopsis tetragonoloba L.) in a Mediterranean environment. Ind Crops Prod. 41: 46-52.

Hothorn T, Bretz F, Westfall P (2008) Simultaneous inference in general parametric models. Biom J. 50: 346-363.

Hymowitz T, Matlock RS (1964) Guar, seed plant and population studies. Oklahoma Agric Exp Station Tech Bull B. 108: 1-35.

Hu C, Ji J, Lu G, Wang X (2002) Water-absorbing trends and germinating characteristics of guar seeds. J Shandong Agric Univ. 33: 281-285.

Iqbal MA (2015) Cluster bean (Cyamopsis tetragonoloba L.) germination and seedling growth as influenced by seed invigoration techniques. Am-Eurasian J Agric Environ Sci. 15: 197-204.

Kigel J (1995) Seed germination in arid and semi-arid regions. In: Kigel J, Galili G (eds) Seed development and germination, Marcel Dekker Inc., New York.

Law CG, Brookmeyer R (1992) Effects of mid-point imputation on the analysis of doubly censored data. Stat Med. 11: 1569-1578.

Liu W, Peffley EB, Powell RJ, Auld DL (2007) Association of seedcoat color with seed water uptake, germination, and seed components in guar (Cyamopsis tetragonoloba (L.) Taub.). J Arid Environ. 70: 29-38.

Lubbe A, Verpoorte R (2011) Cultivation of medicinal and aromatic plants for specialty industrial materials. Ind Crops Prod. 34: 785-801.

Mathur NK (2012) Industrial galactomannan polysaccharides. CRC Press, Taylor \& Francis Group, Boca Raton. 
Motsa MM, Slabbert MM, van Averbeke W, Morey L (2015) Effect of light and temperature on seed germination of selected African leafy vegetables. S Afr J Bot. 99: 29-35.

Mudgil D, Barak S, Khatkar BS (2011) Guar Gum: Processing, properties and food applications - A review. J Food Sci Technol. 51: 409-418.

Onofri A, Gresta F, Tei F (2010) A new method for the analysis of germination and emergence data of weed species. Weed Res. 50: 187-198.

Probert RJ (1992) The role of temperature in germination ecophysiology, In: Fenner M (ed), Seeds-The ecology of regeneration in plant communities. CAB International, Wallingford.

Ramarajan S, Rayan BAS, Joseph HL, Gandhi SA (2013) Seed germination and biochemical changes in Cyamopsis tetragonoloba (L.) Taub (Var. Pusa Naubahar) under salt stress. Res Rev: J Crop Sci Technol. 2, 4-9.

Ranal MA, Santana DGD (2006) How and why to measure the germination process? Rev Bras Bot. 29: 1-11.

Sharma P (2010) Guar Industry Vision 2020: Single vision strategies. NIAM research report, Anurag Bhatnagar, IAS, Jaipur.
Sortino O, Gresta F (2007) Growth and yield performance of five guar cultivars in a Mediterranean environment. Ital J Agron. 4: 359-364.

Teolis I, Liu W, Peffley EB (2009) Salinity effects on seed germination and plant growth of guar. Crop Sci. 49: 637642.

Tripp LD, Lovelace DA, Boring III EP (1977) Keys to profitable guar production. Texas Agric Expt Stn, College Station.

Undersander DJ, Putnam DH, Kaminski AR, Kelling KA, USA Doll JD, Oplinger ES, Gunsolus JL (1991) Alternative field crops manual: guar. Univ. of Wisconsin and Univ. of Minnesota, Madison, WI, USA.

Vaughn SF, Berhow MA, Winkler-Moser JK, Lee E (2011) Formulation of a biodegradable, odor-reducing cat litter from solvent-extracted corn dried distillers grains. Ind Crops Prod. 34: 999-1002.

Vinisky I, Ray DT (1985) Effects of various salts and temperatures on germination in guar. Forage Grain Rep. 64: 102-103. 